\title{
Pollination dynamics, grain weight and grain cell number within the inflorescence and spikelet in oat and wheat
}

\author{
Ari Rajala, Pirjo Peltonen-Sainio \\ MTT Agrifood Research Finland, Jokioinen, Finland; Corresponding Author: ari.rajala@mtt.fi
}

Received 3 December 2010; revised 23 May 2011; accepted 7 July 2011.

\begin{abstract}
Oat (Avena sativa L.) and wheat (Triticum aestivum L.) vary in the structure of their inflorescences and also in how pollination proceeds within the inflorescence. In both species the grain position in the spikelet determines grain weight potential. Primary grains in oat and proximal grains in wheat weigh more than secondary and distal grains. This variation in grain weight can potentially result from differences in post-pollination cell division in the grain. In this study pollination duration and dynamics were analyzed from head samples collected at twoday intervals, starting from the pollination of the most advanced floret. The number of grain cells was determined for individual grains throughout the inflorescence, starting from the pollination event. When mature, grain position in the spikelet and spike was noted and grain weight assessed. Pollination advance in oat proceeded from the uppermost primary floret towards the basal spikelets in ten to eleven days. Within the spikelet, the primary floret was pollinated on average one day earlier than the secondary floret. In wheat, pollination duration was four to five days, starting from the proximal florets in the mid-section of the inflorescence progressing towards the apical and basal spikelets. Proximal florets were pollinated one to two days earlier than distal florets. Maximum cell number in primary grains exceeded that of secondary grains in two oat cultivars. Similarly, primary grains were heavier than secondary grains. Cell number and single grain weight were correlated in terms of grain position in the spikelet (primary - secondary) and cultivar. Oat cultivar Belinda had a higher single grain weight than Fiia, which was also expressed as larger grain cell number. In wheat,
\end{abstract}

proximal grains had higher maximum cell numbers and were also heavier than distal grains. This grain weight gradient was apparent throughout the inflorescence. Consequently, grain cell number is one of the possible regulators of grain-filling capacity in both cereal crops.

Keywords: Cell Number; Distal Grain; Filling Potential; Floret; Oat; Pollination; Primary Grain; Proximal Grain; Secondary Grain; Wheat

\section{INTRODUCTION}

Oat and wheat have different inflorescence structures and the rate of development also differs between the crops. The development in the oat panicle proceeds from the uppermost terminal spikelet downwards to the base of the panicle [1-3], while in wheat the inflorescence develops more synchronously $[4,5]$. In oat the developmental stages of spikelets and timing of pollination differ markedly within the panicle. For example, Bonnett recorded 18 days for the spikelet initiation phase to reach the basal parts of the panicle [6]. Somewhat shorter intra-panicle durations ( 7 - 12 days) were recorded for pollination $[3,6]$. In wheat, the development proceeds from the mid-section of the spike towards the apical and basal sections and initiation of the terminal spikelet at the top of the spike terminates the spikelet initiation phase [4,5]. Pollination begins in proximal florets situated in the middle of the spike and reaches the distal grains in the basal part of the spike within three to seven days $[4,5]$. However, most distal florets fail to set grain if anthesis takes place more than three days after pollination in the most advanced proximal florets [5].

The oat panicle probably exhibits greater plasticity to respond to favorable conditions through increased floret and grain set than the wheat spike, which has a terminal spikelet [7]. It also takes a long time for both floral ini- 
tiation and advance of pollination downwards in the panicle $[3,6]$. This probably exposes different parts of panicle to various growing conditions during floral development and grain filling, which may result in within panicle heterogeneity in grain weight. Also, a long pollination period may increase the potential exposure of the oat florets to Fusarium infections. Oat samples expressed the highest mycotoxin levels when compared with wheat and barley (Hordeum vulgare L.) under Scandinavian growing conditions [8].

The single grain weight is dependent on the position of the spikelet in the head and on the grain position in the spikelet, the latter being the more important factor in both species. In oat, grains situated at the top or upper section of the panicle are typically slightly heavier than grains produced in the lower section of the panicle, whereas the primary grain clearly outperforms secondary and tertiary grains [3,9,11-13]. In wheat, spikelets situated in the mid-section of the spike produce heavier grains compared with apical and basal spikelets [14-17], while within the spikelet proximal grains clearly exceed the distal grains in single grain weight [15,17-19].

The primary grain domination seems to be very strong trait in oat as even elimination of the primary grain fails to enhance grain-filling capacity of the secondary grain such that it reaches that of the primary grain $[3,11]$. In wheat, elimination of the proximal grains within the spikelet increased the occurrence and dry weight of the remaining (third and fourth) grain above that of the grains of intact spikelets $[4,18,20]$. On the other hand, sink size reductions in wheat, induced by removing whole spikelets, resulted only in modest, if any, effects on weight of the remaining grains [14,21,22].

Several factors contribute to within inflorescence variation in individual grain weight and possibly interact. Intra-inflorescence and intra-spikelet differences in development rate and time of pollination potentially affect the duration of the grain-filling period and grain-filling capacity of oat $[3,6,11]$. Differences in vascular transport capacity within the spike and spikelet may regulate the filling capacity of the grain. Primary grain in oat and proximal grains in wheat have more efficient assimilate transport systems compared with secondary and distal grains $[6,10,18,23]$.

Ultimately, the grain itself could play an active role in the grain-filling process [24]. The rate and duration of post-pollination cell division and consequent number of cells formed in the grain could set the limit for the individual grain-filling capacity [24]. A positive relationship between grain cell number and grain weight was reported for wheat [20,25] and oat [3]. Thus, grain growth is controlled by grain characteristics developed after pollination and prior the active grain-filling process. Both genetic and environmental factors have an effect on grain growth capacity. Genetic factors set certain limits to grain size, while the environmental conditions control the degree to which this potential is fulfilled [24]. There are also indications that growing conditions prior to pollination may determine a grain's potential to accumulate carbohydrates. Calderini et al. [26] reported that exposure to high temperature during floret development (prior to anthesis) resulted in reduction in carpel weight at anthesis and in final grain weight. Similarly, genotypes of lighter carpel weight produced lighter grains [27].

The aim of the study was to characterize pollination dynamics within the inflorescence and spikelet in two oat and wheat cultivars differing in growing time requirement. Also, grain position effect on single grain weight within the inflorescence and spikelet was evaluated. Further aim was to determine potential association between grain cell number and single grain weight in two oat and a wheat cultivar.

\section{MATERIALS AND METHODS}

\subsection{Pollination Dynamics}

The inflorescence samples for pollination dynamics studies were collected from field experiments carried out in Jokioinen $\left(60^{\circ} 48^{\prime} \mathrm{N}, 23^{\circ} 28^{\prime} \mathrm{E}\right)$ in 2009 . Early and late maturing cultivars of oat and wheat were selected to study the potential effect of earliness on pollination progress. At the onset of heading, 40 plants per plot at an identical development stage were marked with adhesive tape for sampling (one plot per cultivar). The pollination of the most advanced floret was determined according to Waddington et al. [28]. The most advanced floret of the main shoot inflorescence was identified and when the stigmatic branches were wide open and clusters of pollen were visibly attached to them, pollination was determined to be taking place. From that date forward inflorescence samples ( 4 per collection time) were collected three times a week to study the progress of pollination in different positions of the inflorescence and within the spikelet. The oat cultivars were Eemeli (early type) and Belinda (late type), and wheat cultivars were Anniina (early type) and Amaretto (late type). Duration from pollination of the most advanced floret to other florets was determined in days and as growing degree days $\left({ }^{\circ} \mathrm{Cd}\right.$, base temperature $5^{\circ} \mathrm{C}$ ).

\subsection{Grain Cell Number}

The cell number component of the study comprised 
two different experiments carried out for research purposes other than potential association between grain cell number and grain weight reported in this paper. Oat cultivars Belinda and Fiia were grown at the Finnish Official Variety Trial site at Jokioinen in 2006. Plot size in all field experiments was $10 \mathrm{~m}^{2}$. Common cultivation practices were applied in experiments. Oat was sown at rate of 500 and wheat at rate of 600 viable seeds per $\mathrm{m}^{2}$. Compound NPK-fertilizer (20-3-8) was applied at rate of $80 \mathrm{~kg} \cdot \mathrm{N} / \mathrm{ha}$ for oat and $100 \mathrm{~kg} \mathrm{~N} / \mathrm{ha}$ for wheat. Plots had been ploughed in autumn, cultivated in spring and seed and fertilizer were applied with placement drill. Spring wheat cultivar Amaretto was grown in 2007 in a large, plastic covered greenhouse $(20 \times 30 \mathrm{~m})$ with automatic control of temperature and watering. Amaretto was sown with a placement drill (10 sowing rows, $12.5 \mathrm{~cm}$ apart) in plots of $7.5 \mathrm{~m}^{2}$ using 350 viable seeds per $\mathrm{m}^{2}$. NPKfertilizer (21-3-9) was applied at rate of $120 \mathrm{~kg} \mathrm{~N} / \mathrm{ha}$. Marking the plants to be collected and determination of pollination was carried out as described previously (one plot per cultivar). Oat panicle samples were collected 1, $4,7,10,14$ and 18 days after pollination (DAP) and wheat ears 2, 4, 6, 8, 10, 12 and 16 DAP. Inflorescences were fixed for 24 hours in acetic acid/ethanol (75/25, $\mathrm{vol} / \mathrm{vol}$ ) and thereafter stored in $70 \%$ ethanol under cool and dark conditions. Advance of pollination in different positions of the inflorescences was determined and the cell numbers were assessed in pollinated grains. When grain cell nuclei number started to decline and starch accumulation was clearly visible, counting ceased. Cell number of the developing grains was determined according to the slightly modified procedure introduced by Tuberosa et al. [29]. The individual inflorescences, stored in ethanol, were rinsed three times with deionised water and placed in deionised water for $5 \mathrm{~min}$ at room temperature. After removal of glumes, paleas and lemmas, caryopsis were placed in $1 \mathrm{M} \mathrm{HCl}$ and kept for $30 \mathrm{~min}$ on ice and $20 \mathrm{~min}$ at $60^{\circ} \mathrm{C}$ in a water-bath. After three rinses with deionised water, samples were placed in Feulgen's reagent (Schiff) for $4 \mathrm{~h}$ in the dark at room temperature. After stain removal with three rinses, samples were macerated in a sodium-acetate-buffered $(\mathrm{pH}$ 4.8) solution of cellulase (Onozuka R10) of 5\% (1 - 4 DAP) and $10 \%$ (8 - 12 DAP) for $17 \mathrm{~h}$ at $37^{\circ} \mathrm{C}$. Stained cell nuclei were counted in a haemocytometer (FuchsRosenthal) at $50 \times$ magnification. Numbers of nuclei in four separate blocks of squares (total of 64 squares) were counted from two separate sub-samples.

Mature inflorescences were collected for single grain analyses. Each grain from the inflorescence was scaled and the position within the inflorescence and within the spikelet was marked. Inflorescences collected for both cell number and single grain analyses were chosen to be identically structured in order to reduce the inconsis- tency caused by varying inflorescence structure. Mean values and standard errors for the means were calculated using MS-Excel 2000.

\section{RESULTS}

\subsection{Pollination Dynamics}

In oat advance in pollination proceeded from the uppermost primary floret towards the basal spikelets (Figure 1). Within the spikelet, on average, the primary floret was pollinated one day prior to the secondary floret. The last of the basal spikelets was pollinated ten to eleven days later than the uppermost spikelet, which is equivalent to 100 to $110{ }^{\circ} \mathrm{Cd}$ (Figure 1). In wheat, pollination advanced faster than in oat and by four to five days after pollination of the most advanced proximal grains in the mid-section of the ear all florets throughout the ear had been pollinated. This is equivalent to 40 to $50{ }^{\circ} \mathrm{Cd}$ (Table 1). Apical spikelets tended to be pollinated prior to basal spikelets in both wheat cultivars. No marked cultivar differences in pollination dynamics were recorded for either species (Figure 1, Table 1).

\subsection{Cell Number and Grain Weight}

In wheat, proximal grains had higher maximum cell number and were also heavier than distal grains (Figure 2). This was the case throughout the ear. Usually, there were two proximal and one or two distal grains in each of the spikelets studied. However, in some spikelets, also the fifth, the most central floret, seemed to be pollinated. These were found exclusively, though rarely, in the spikelets in the mid-section of the ear. The recorded cell number of these florets was always low, averaging only 24,000 cells per grain. These developing grains were apparently aborted during the early phase of grain filling

Table 1. Required growing degree days $\left({ }^{\circ} \mathrm{Cd}\right.$, from sowing, base temperature $5^{\circ} \mathrm{C}$ ) for floret pollination in different ear positions of wheat cultivars Anniina and Amaretto.

\begin{tabular}{ccccc}
\hline & \multicolumn{2}{c}{ Anniina } & \multicolumn{2}{c}{ Amaretto } \\
\cline { 2 - 5 } & \multicolumn{3}{c}{ proximal grain distal grain proximal grain distal grain } \\
\hline spikelet & ${ }^{\circ} \mathrm{Cd}$ & ${ }^{\circ} \mathrm{Cd}$ & ${ }^{\circ} \mathrm{Cd}$ & ${ }^{\circ} \mathrm{Cd}$ \\
1 & 573 & 599 & 613 & 626 \\
2 & 568 & 599 & 603 & 619 \\
3 & 563 & 595 & 599 & 619 \\
4 & 553 & 579 & 595 & 613 \\
5 & 558 & 584 & 595 & 619 \\
6 & 568 & 589 & 608 & 626 \\
7 & 589 & 599 & 619 & 639 \\
8 & 595 & & 646 & 647 \\
9 & & & 653 & \\
\hline
\end{tabular}




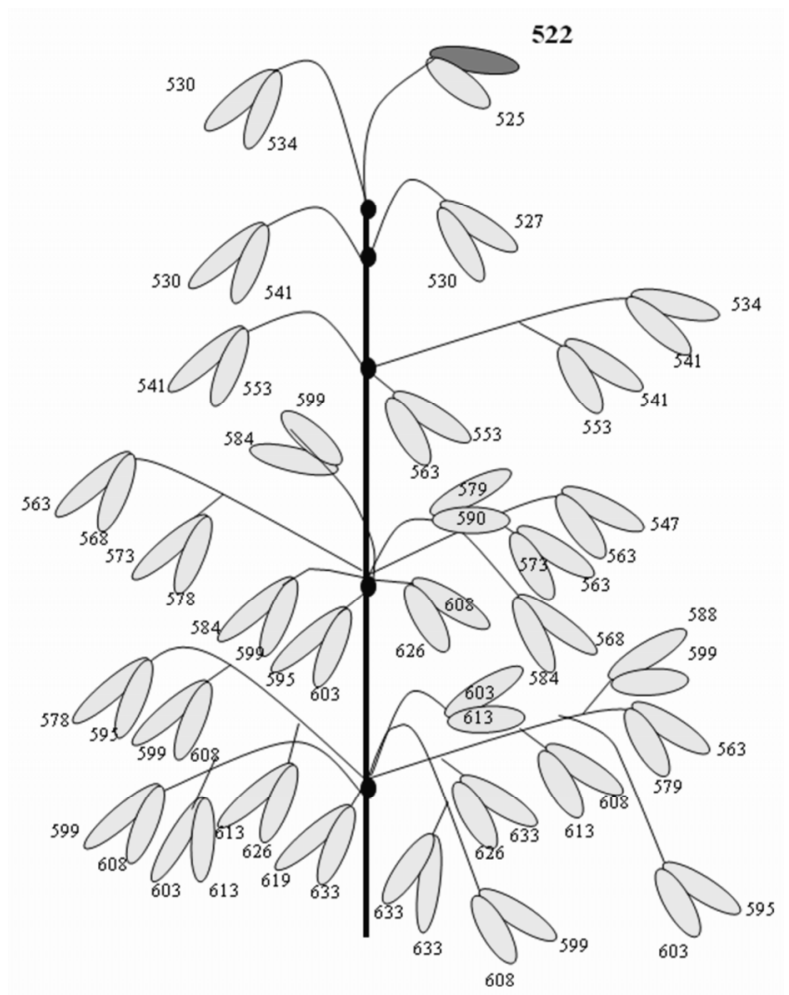

Eemeli

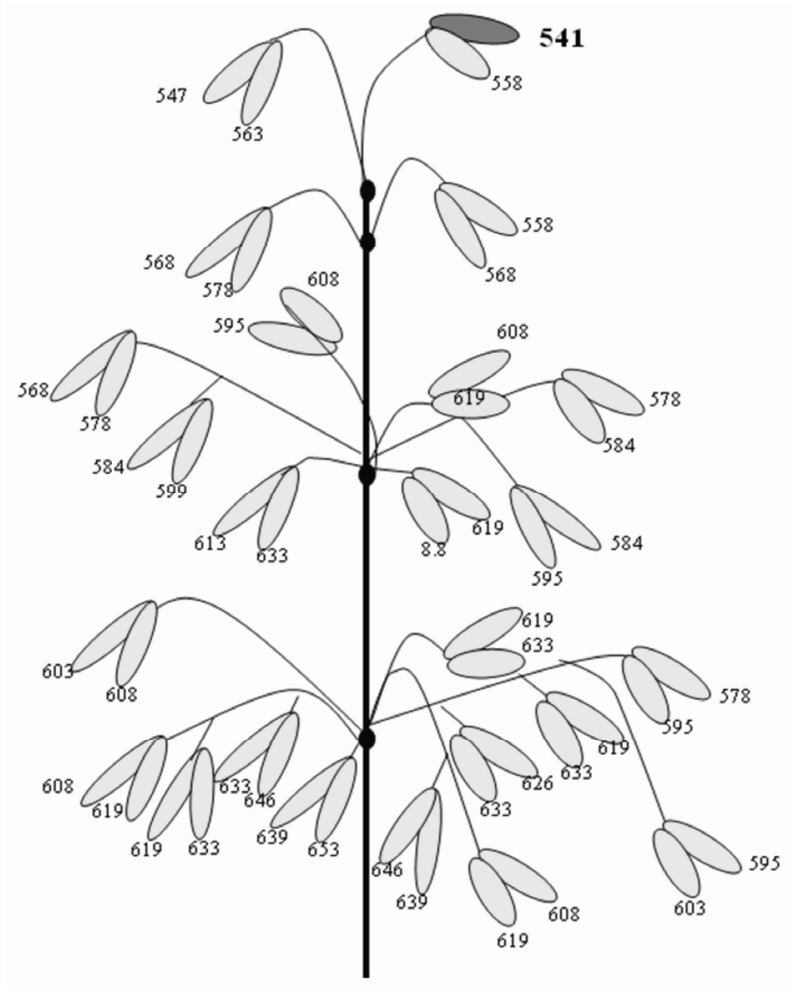

Belinda

Figure 1. Schematic presentation of oat panicle and required growing degree days $\left({ }^{\circ} \mathrm{Cd}\right.$, from sowing, base temperature $\left.5^{\circ} \mathrm{C}\right)$ for floret pollination in different panicle positions of cultivars Eemeli and Belinda. Value represents the mean of four panicles.

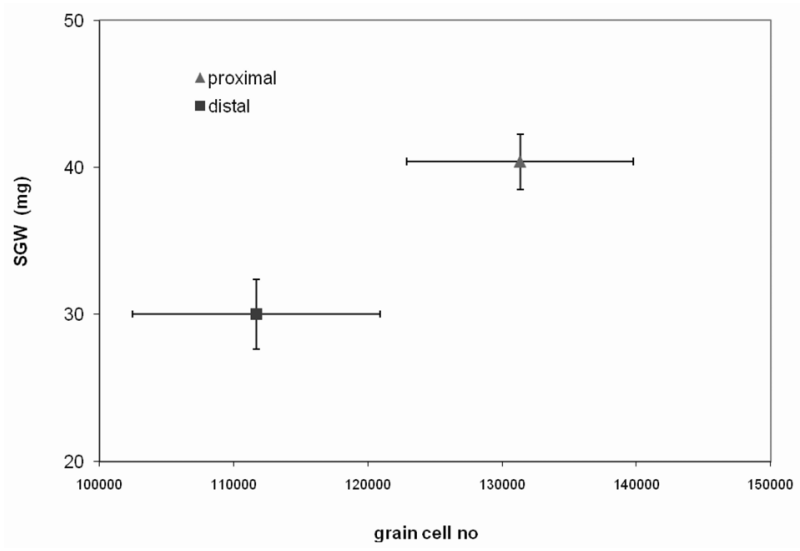

Figure 2. Single grain weight (SGW) and maximum grain cell number in proximal and distal grains in wheat cv. Amaretto. Bars indicate standard error of means.

and were not found in the mature ears. Grain weight varied within the wheat spikelet and ear (Figure 3). Proximal grains were heavier than distal grains and the grains produced in spikelets of the mid-ear weighed more. Proximal grains produced $74 \%$ of the total ear yield.

In oat, lower whorls tended to have lower grain cell numbers than the uppermost whorls (data not shown). In

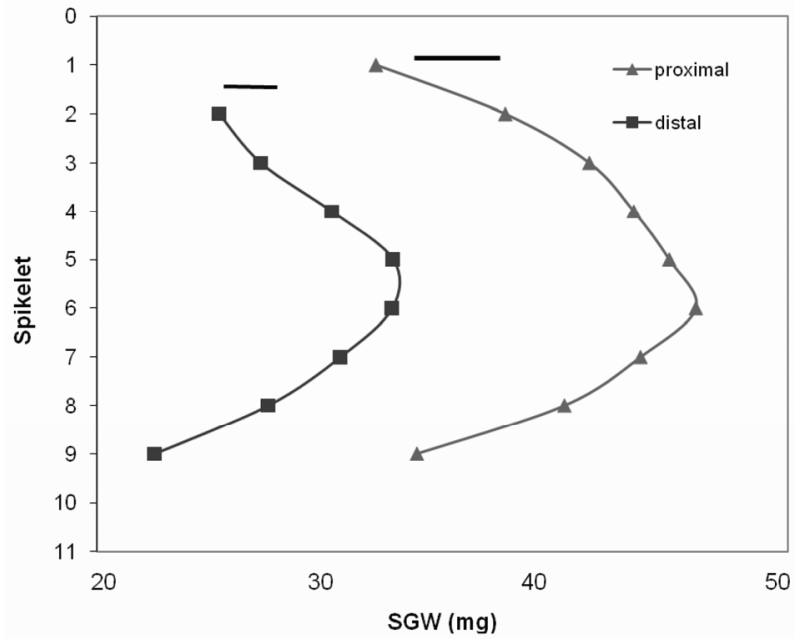

Figure 3. Single grain weight (SGW) of proximal (blue line) and distal (red line) grains in wheat cv. Amaretto. Spikelet 1 to 9 represents top and basal positions in the spike. Bars indicate standard error of means.

both oat cultivars maximum cell number in primary grains exceeded that of secondary grains and the difference was apparent in all branches throughout the panicle. Similarly, primary grains weighed more than secondary grains (Table 2). This resulted in primary grain 
Table 2. Single grain weight (SGW) and standard error of means (stderr) of primary and secondary grain of oat cultivars Belinda and Fiia.

\begin{tabular}{|c|c|c|c|c|c|c|c|c|}
\hline & \multicolumn{4}{|c|}{ Belinda } & \multicolumn{4}{|c|}{ Fiia } \\
\hline & \multicolumn{2}{|c|}{ primary grain } & \multicolumn{2}{|c|}{ secondary grain } & \multicolumn{2}{|c|}{ primary grain } & \multicolumn{2}{|c|}{ secondary grain } \\
\hline & SGW & stderr & SGW & stderr & SGW & stderr & SGW & stderr \\
\hline whorl & $\mathrm{mg}$ & & $\mathrm{mg}$ & & $\mathrm{mg}$ & & $\mathrm{mg}$ & \\
\hline 1 & 48,9 & 2,03 & 26,5 & 0,28 & 46,3 & 1,17 & 28,7 & 1,44 \\
\hline 2 & 45,0 & 5,16 & 29,5 & 1,58 & 41,3 & 1,45 & 22,2 & 3,58 \\
\hline 3 & 49,9 & 1,18 & 29,4 & 1,85 & 39,1 & 2,84 & 25,0 & 1,07 \\
\hline 4 & 44,2 & 2,31 & 28,7 & 1,12 & 39,5 & 1,79 & 24,7 & 0,94 \\
\hline 5 & 41,3 & 1,03 & 29,0 & 0,98 & 38,2 & 0,90 & 23,1 & 0,93 \\
\hline
\end{tabular}

Whorls 1 to 5 represent top and basal positions in the panicle.

domination in yield formation. In panicles of Belinda and Fiia, $61 \%$ and $62 \%$ of the yield was produced by the primary grains, respectively. Cell number and single grain weight were correlated in terms of grain position in the spikelet (primary - secondary) and cultivar. Belinda had higher single grain weight and higher grain cell number compared with Fiia (Figure 4).

The contribution of different whorls to panicle yield was similar in both oat cultivars and most yields $(66 \%)$ was produced in the two lowest whorls of the panicle. There was also a tendency for lower whorls to produce slightly lighter primary and secondary grains in both cultivars (Table 2).

\section{DISCUSSION}

\subsection{Advance of Pollination within the Inflorescence}

Pollination advance (Figure 1 and Table 1) was similar to that reported for oat grown in the USA [6] and for

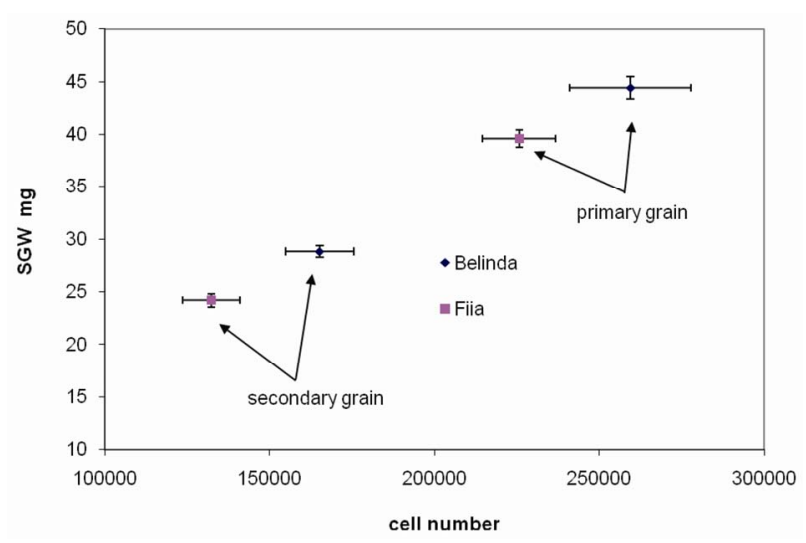

Figure 4. Single grain weight (SGW) and maximum grain cell number in primary and secondary grain of oat cultivars Belinda and Fiia. Bars indicate standard error of means. wheat grown in Australia [4,5]. An apparent floret hierarchy in pollination was evident for both species: the primary floret in oat and proximal floret in wheat were pollinated prior to the accompanying florets irrespective of the spikelet position in the inflorescence (Figure 1 and Table 1). Apical development rate in cereals is characteristically accelerated under long day conditions [30,31]. However, when comparing the results of this study and published results, pollination seemed to proceed rather similarly regardless of day length. Pollination in oat proceeded from the uppermost primary floret towards the basal spikelets (Figure 1).

A similar phenomenon was apparent also horizontally at the whorl level. The pollination proceeded from the outermost spikelet towards the spikelets situated closest to the panicle rachis (Figure 1). In general, it seems that oat spikelets are pollinated more or less in the same order as they appear from the flag leaf sheath at panicle emergence.

In wheat the pollination was more synchronous in terms of days and cumulative degree days when compared with oat. It took four to five days to complete pollination in wheat compared with ten to eleven days in oat. A relatively long pollination period in oat potentially exposes the grains in different positions of the panicle and whorl to a range of environmental conditions. This may be reflected in varying grain-filling capacity and yielding potential in the panicle. Moreover, a long pollination period can increase the risk of Fusarium infection. The infection is favored by precipitation or a humid microclimate during pollination and early grain filling [8, 32]. Oat has twice as long a pollination period as wheat, and therefore there is potentially a higher risk of Fusarium infection in some parts of the panicle. The advance of pollination was similar in early and late maturing cultivars in both species (Figure 1, Table 1). 


\subsection{Grain Weight and Grain Position in Spikelet and Inflorescence}

Grain weight was primarily dependent on grain position within the spikelet for both species. Proximal grain for wheat and primary grain for oat were heavier than their counterpart grains (Figure 3, Table 2). This is in accordance with earlier reports for both species $[3,13,15$ 17]. Higher grain weight resulted in primary and proximal grain domination in yield production: $61 \%$ and $74 \%$ of the grain yield was produced by primary and proximal grain in oat and wheat, respectively.

These values, recorded for cultivars adapted to extremely short growing seasons, are well in line with published values, in which primary grains of oat were reported to produce $60 \%$ to $70 \%$ of the panicle grain yield $[9,12]$ and up to $80 \%$ of the proximal grains in wheat $[15$, 16]. Accordingly, the gradient in grain yield potential within the spikelet appears similar irrespective of growing conditions. Grain position within the ear in wheat had an apparent effect on grain weight (Figure 3). Both proximal and distal grains in the mid-section of the ear outperformed their counterpart grains in the apical and basal sections. Typically, wheat grains produced in the mid-section of the ear were the heaviest [14-16]; while in oat, the upper whorls produced heavier grains than the lower whorls (Table 2). This is in accordance with published data [3, 10,12,13]. Accordingly, the individual grain filling capacity at the different positions in the panicle and whorl slightly decreases towards the base. But when grain- filling capacity is surveyed at the whorl level, the assimilate transport capacity or the sink strength of the whorl appears to be directly dependent on the number of grains in the whorl. This was evident in figures for the grain yield produced in each whorl. The two lowest whorls produced $68 \%$ of the grains and $66 \%$ of the grain yield. The greater number and area of vascular tissue in the lower whorls facilitate almost as efficient assimilate transport at grain level as in top whorls [10]. The slight grain weight gradient in favor of grains in the uppermost whorls is likely to be due to increased vascular transport capacity per grain [10]. The grain weight gradient from primary to secondary and proximal to distal grains was clear for both species (Figures 2-4). This difference is likely attributable to the differences in assimilate transport capacity within the grains in the spikelet in both species $[6,10,18,23]$.

The filling capacity of the secondary grains in oat is apparently restricted. Elimination of the primary grain improved the single grain weight of the secondary grains, but they invariably failed to reach the weight of the intact primary grains $[3,11]$. Thus, the potential weight of the secondary grain must be restricted as it always fails to reach that of the primary grains, even when there is reduced assimilate competition within the spikelet and thereby surplus assimilate availability for secondary grain. In oat, the number and area of vascular tissue transporting assimilates decreases towards the top of the panicle $[6,10]$. Nevertheless, the heaviest grains are typically produced in the top part of the panicle $[3,11,13]$ because of the lower grain number at the apex of the panicle and greater vascular transport capacity per grain [10].

\subsection{Grain Cell Number and Grain Weight}

When individual grain cell number was recorded and maximum cell number and grain weight of a particular grain were compared, no correlation was established (data not shown). However, when the relationship between grain cell number and single grain weight was investigated at primary-secondary and proximal-distal grain level; there was an apparent correlation for both species (Figures 2 and 4). According to these results it seems that the number of cells formed in the endosperm affects the potential weight of the grain within the spikelet. Similar indications were reported in for wheat previously [33-35], and for oat [3] and other cereal species [36-39]. Egli [24] emphasized the role of the seed itself in establishing filling capacity of the individual seed. According to Egli [24] genotype defines the limit for potential grain size, while the growing conditions regulate the degree to which this potential is fulfilled. In this study, it was not possible to measure the environmental effect, but the genotype effect was evident in oat: Belinda clearly outperformed Fiia in terms of grain cell number and grain weight (Figure 4). A similar difference was noted also in our earlier preliminary work [3]. In addition, barley and wheat genotypes with higher grain weight have had greater grain cell numbers $[25,34$, 39]. Thus, these findings support the hypothesis that cultivar differences in grain characteristics are associated with grain-filling capacity. Grain cell number is an attractive and a likely candidate for determining potential grain weight. Single grain weight is known to be cultivar dependent and more stable over contrasting growing conditions when compared with grain number per plant or unit land area, which fluctuate more [40,41]. This supports the hypothesis that cultivar differences in single grain weight could originate from limit induced by grain setting for grain growth potential.

This study revealed differences in numbers of grain cells at different spikelet positions. Possibly differences in assimilate transport capacity within the spikelet also control the grain-filling capacity through post-pollination cell division. Another possible reason relates to hormonal control as cell division in plant tissue is hormonally regulated. Peak concentrations of hormones, 
their relative concentrations, timing of occurrence during the growth cycle and change in tissue sensitivity to hormones play a complex role in plant development and growth processes [42].

Higher cytokinin and auxin levels were shown to be associated with higher grain weight in cereals [42-46]. Growing conditions, especially stresses, alter hormone balance. For example, drought-induced increase in abscisic acid concentration inhibited cell division in developing grains, reducing grain weight in wheat and maize (Zea mays) [36,37,47]. Thus, observed differences in grain cell number could be hormonally regulated.

\section{CONCLUSIONS}

Oat and wheat differed markedly in how pollination proceeded within the inflorescence. The entire wheat ear was pollinated in four to five days, whereas in the oat panicle the pollination period lasted ten to eleven days. For both species, pollination advanced similarly in early and late maturing cultivars adapted to the short growing season of northern Europe. The position of the grain in the spikelet strongly determined the grain weight potential .in both species. Grain weight and number of cells formed in the grain seemed to associate at grain position level. Hence, grain cell number may establish dry matter accumulation potential of the grain.

\section{ACKNOWLEDGEMENTS}

This study was partly financed by EU INCO-MED project WatNitMED (INCO-CT-2004-509107), Management Improvements of Water and Nitrogen Use Efficiency of Mediterranean Strategic Crops (Wheat and Barley). The authors are grateful for the technical assistance of Aino Lahti and Leila Salo. Dr Jonathan Robinson is acknowledged for linguistic revision.

\section{REFERENCES}

[1] Afors, M., Ohlander, L. and Stendahl, F. (1988) Strasädens utveckling I. en literaturstudie och beskrivning av en skala för bestämning av strasädens ax-respektive vippanlag. Sveriges Lantbruksuniversitet, Institution för växtodlingslärä, Uppsala, 1-75.

[2] Peltonen-Sainio, P. and Pekkala, T. (1993) Numeric codes for developmental stages of oat apex in the growing conditions of southern Finland. Agricultural Science in Finland, 2, 329-336.

[3] Rajala, A. and Peltonen-Sainio, P. (2004) Intra-plant variation in progress of cell division in developing oat grains: A preliminary study. Agricultural and Food Science, 13, 163-169. doi:10.2137/1239099041837987

[4] Rawson, H.M. and Evans, L.T. (1970) The pattern of grain growth within the ear of wheat. Australian Journal of Biological Science, 23, 753-764.

[5] Evans, L.T., Bingham, J. and Roskams, M.A. (1982) The pattern of grain set within ears of wheat. Australian
Journal of Biological Science, 25, 1-8.

[6] Bonnett, O.T. (1961) The oat plant: Its histology and development. Bulletin 672. University of Illinois. Agricultural Experiment Station.

[7] Peltonen-Sainio, P. and Peltonen, J. (1995) Floret set and abortion in oat and wheat under high and low nitrogen regimes. European Journal of Agronomy, 4, 253-262.

[8] Langseth, W. and Rundberget, T. (1999) The occurrence of HT-2 toxin and other trichothecens in Norwegian cereals. Mycopathologia, 147, 157-165. doi:10.1023/A:1007153416269

[9] Youngs, V.L. and Shands, H.L. (1974) Variation in oat kernel characteristics within the panicle. Crop Science, 14, 578-580. doi:10.2135/cropsci1974.0011183X001400040026x

[10] Housley, T.L. and Peterson, D.M. (1982) Oat stem vascular size in relation to kernel number and weight. I. controlled environment. Crop Science, 22, 259-263. doi:10.2135/cropsci1982.0011183X002200020014x

[11] Tibelius, A. and Klinck, H.R. (1987) Effects of artificial reduction in panicle size on weight of secondary seeds in oats (Avena sativa L.). Canadian Journal of Plant Science, 67, 621-628. doi:10.4141/cjps87-088

[12] Crampton, M.W., Moot, D.J. and Martin, R.J. 1997 Kernel weight distribution within oat (Avena sativa L.) panicles. Proceedings Agronomy Society of New Zealand, 27, 83-87.

[13] Doehlert, D.C., McMullen, M.S. and Riveland, N.R. (2002) Sources of variation in oat kernel size. Cereal Chemistry, 79, 528-534. doi:10.1094/CCHEM.2002.79.4.528

[14] Miralles, D.J. and Slafer, G.A. (1995) Individual grain weight responses to genetic reduction in culm length in wheat as affected by source-sink manipulations. Field Crops Research, 43, 55-66. doi:10.1016/0378-4290(95)00041-N

[15] Stoddard, F.L. (1999) Variation in grain mass, grain nitrogen, and starch B-granule content within wheat heads. Cereal Chemistry, 76, 139-144. doi:10.1094/CCHEM.1999.76.1.139

[16] Duggan, B.L. and Fowler, D.B. (2006) Yield structure and kernel potential of winter wheat on the Canadian prairies. Crop Science, 46, 1479-1487. doi:10.2135/cropsci2005.06-0126

[17] Rajala, A., Hakala, K., Mäkelä, P., Muurinen, S. and Peltonen-Sainio, P. (2009) Spring wheat response to timing of water deficit through sink and grain filling capacity. Field Crops Research, 114, 263-271. doi:10.1016/j.fcr.2009.08.007

[18] Simmons, S.R. and Moss, D.N. (1978) Nitrogen and dry matter accumulation by kernels formed at specific florets in spikelets of spring wheat. Crop Science, 18, 139-143. doi:10.2135/cropsci1978.0011183X001800010037x

[19] Calderini, D.F. and Ortiz-Monasterio, I. (2003) Grain position affects grain macronutrient and micronutrient concentrations in wheat. Crop Science, 43, 141-151. doi:10.2135/cropsci2003.0141

[20] Radley, M. (1978) Factors affecting grain enlargement in wheat. Journal of Experimental Botany, 29, 919-934. doi:10.1093/jxb/29.4.919

[21] Ma, Y-Z., MacKown, C.T. and Van Sanford, D.A. (1996) Differential effects of partial spikelet removal and defoliation on kernel growth and assimilate partitioning 
among wheat cultivars. Field Crops Research, 47, 201209. doi:10.1016/0378-4290(96)00016-0

[22] Cartelle, J., Pedró, A., Savin, R. and Slafer, G.A. (2006) Grain weight responses to post-anthesis spikelet-trimming in an old and modern wheat under Mediterranean conditions. European Journal of Agronomy, 25, 365-371. doi:10.1016/j.eja.2006.07.004

[23] Hanif, M. and Langer, R.H.M. (1972) The vascular system of spikelet in wheat (Triticum aestivum). Annals of Botany, 36, 721-727.

[24] Egli, D.B. (2006) The role of seed in the determination of yield in grain crops. Australian Journal of Agricultural Research, 57, 1237-1247 doi:10.1071/AR06133

[25] Brocklehurst, P.A. (1977) Factors controlling grain weight in wheat. Nature, 266, 348-349. doi: $10.1038 / 266348 \mathrm{a} 0$

[26] Calderini, D.F., Abeledo, L.G., Savin, R. and Slafer, G.A. (1999) Effect of temperature and carpel size during pre-anthesis on potential grain weight in wheat. Journal of Agricultural Science in Cambridge, 132, 453-459. doi:10.1017/S0021859699006504

[27] Calderini, D.F. and Reynolds, M.P. (2000) Changes in grain weight as a consequence of de-graining treatments at pre- and post-anthesis in synthetic hexaploid lines of wheat (Triticum durum x T. tauschii). Australian Journal of Plant Physiology, 27, 183-191.

[28] Waddington, S.R., Cartwright, P.M. and Wall, P.C. (1983) A quantitative scale of spike initiation and pistil development in barley and wheat. Annals of Botany, 51, 119-130.

[29] Tuberosa, R., Sanguineti, M.C., Stefanelli, S. and Quarrie, S. (1992) Number of endosperm cells and endosperm abscisic acid content in relation to kernel weight in four barley genotypes. European Journal of Agronomy, 1, 125-132.

[30] Craufurd, P.Q. and Cartwright, P. (1989) Effect of photoperiod and chlormequat on apical development and growth I a spring wheat (Triticum aestivum) cultivar. Annals of Botany, 63, 515-525.

[31] Peltonen-Sainio, P. and Rajala, A. (2007) Duration of vegetative and generative development phases in oat cultivars released since 1921. Field Crops Research, 101, 72-79. doi:10.1016/j.fcr.2006.09.011

[32] Koch, H-J., Pringas, C. and Maerlaender, B. (2006) Evaluation of environmental and management effects on Fusarium head blight infection and deoxynivalenol concentration in the grain of winter wheat. European Journal of Agronomy, 24, 357-366.

[33] Singh, B.K. and Jenner, C.F. (1982) Association between concentrations of organic nutrients in the grain, endosperm cell number and grain dry weight within the ear of wheat. Australian Journal of Plant Physiology, 9, 83-95. doi:10.1071/PP9820083

[34] Chojecki, A.J.S., Bayliss, M.W. and Gale, M.D. (1986) Cell production and DNA accumulation in the wheat endosperm and their association with grain weight. Annals of Botany, 58, 809-817.

[35] Gao, X., Francis, D., Ormrod, J.C. and Bennett, M.D. (1992) Changes in cell number and cell division activity during endosperm development in allohexaploid wheat, Triticum aestivum L. Journal of Experimental Botany, 43, 1603-1609. doi:10.1093/jxb/43.12.1603

[36] Myers, P., Setter, T., Madison, J. and Thompson, J. (1990) Abscisic acid inhibition of endosperm cell division in cultured maize kernels. Plant Physiology, 94, 1330-1336. doi:10.1104/pp.94.3.1330

[37] Ober, E., Setter, T., Madison, J., Thompson, J. and Shapiro, P. (1991) Influence of water deficit on maize endosperm development. Enzyme activities and RNA transcripts of starch and zein synthesis, cell division and ABA. Plant Physiology, 97, 154-164. doi:10.1104/pp.97.1.154

[38] Barrôco, R.M., Peres, A., Droual, A.-M., De Veylder, L., Ngyen, L.S.L., Wolf, J.D., Mironov, V., Peerbolte, R., Beemster, G.T.S., Inzé, D., Broekaert, W.F. and Frankard, V. (2006) The cyclin-dependent kinase inhibitor Orysa; KRP1 Plays an important role in seed development of rice. Plant Physiology, 142, 1053-1064. doi:10.1104/pp.106.087056

[39] Cochrane, M.P. and Duffus, C.M. (1983) Endosperm cell number in cultivars of barley differeing in grain weight. Annals of Applied Biology, 102, 177-181. doi:10.1111/j.1744-7348.1983.tb02678.x

[40] Peltonen-Sainio, P., Kangas, A., Salo, Y. and Jauhiainen, L. (2007) Grain number dominates grain weight in cereal yield determination: evidence basing on 30 years' multilocation trials. Field Crops Research, 100, 179-188. doi:10.1016/j.fcr.2006.07.002

[41] Sadras, V.O. (2007) Evolutionary aspects of the trade- off between seed size and number in crops. Field Crops Research, 100, 125-138. doi:10.1016/j.fcr.2006.07.004

[42] Michael, G. and Beringer, H. (1980) The role of hormones in yield formation. Physiological aspects of crop productivity, Proceedings of 15th IPI-Collection, International Potash Institute, Bern, 85-115.

[43] Mounler, M., Bangerth, F. and Story, V. (1980) Gibberellin-like substances and indole type auxins in developing grains of normal and high-lysine genotypes of barley. Physiologia Plantarum, 48, 568-573. doi:10.1111/j.1399-3054.1980.tb03306.x

[44] Yang, J., Zhang, J., Huang, Z., Wang, Z., Zhu, Q. and Liu, L. (2002) Correlation of cytokinin levels in the endosperms and roots with cell number and cell division activity during endosperm development in rice. Annals of Botany, 90, 369-377. doi:10.1093/aob/mcf198

[45] Xu, G., Zhang, J., Lam, H.M., Wang, Z. and Yang, J. (2007) Hormonal changes are related to the poor grain filling in the inferior spikelets of rice cultivated under non-flooded and mulched condition. Field Crops Research, 101, 53-61. doi:10.1016/j.fcr.2006.09.008

[46] Yang, J., Zhang, J., Wang, Z., Liu, K. and Wang, P. (2006) Post-anthesis development of inferior and superior spikelets in rice relation to abscisic acid and ethylene. Journal of Experimental Botany, 57, 149-160. doi:10.1093/jxb/erj018

[47] Nicolas, M.E., Gleadow, R.M. and Dalling, M.J. (1985) Effect of post-anthesis drought on cell division and starch accumulation in developing wheat grains. Annals of Botany, 55, 433-444. 